\title{
Assessment of health promoting behaviors in relation to physical activity in elderly
}

\author{
Suha J. Abdul- Lateef \\ College of Nursing, University of Mosul, Mosul, Iraq \\ Correspondence: Suha J. Abdul- Lateef. Suha.jaber@uomosul.edu.iq.
}

(Ann Coll Med Mosul 2018; 40 (1): 31-35).

Received: $1^{\text {st }}$ May 2014; Accepted: $15^{\text {th }}$ Apr. 2018.

\section{ABSTRACT}

Background: Health promotion refers to those behaviors in which a person is engaged in to prevent disease and maximize health, it is beneficial in older adult in reducing disability and improving quality of life.

Objective: To assess these behaviors in relation to health outcomes among old population for the last five years of their lives in Mosul city.

Methodology: After obtaining a formal consent from the participant, a random sample of 112 old persons were included in this case series study. They were collected from elderly home in Mosul and from two main health centers, data collected in a period from the first January to the end of March in 2011. Peers correlation was used to examine this relationship.

Result: The study founded that exercise is predictive for less Basic Activities of Daily Living limitation (washing, bathing, eating, dressing, getting in/out of bed), Balanced diet was also found to be predictive for fewer Limitation of Instrumental Activities of Daily Living (moving from room to room, walking out of door, shopping, doing own house work). Inverse relations were found between stress management and both BADL/IADL. It was also founded between subjectively related health with both exercise and healthy balanced diet.

Conclusion: The study concluded that old population in Mosul were poorly engaged in a real health promoting behaviors, mainly for exercise and balanced diet.

Recommendation: The study recommend that a special attention should be given for old population Through a health promoting centers to increase their years of healthy life.

Keywords: Balanced diet, exercise, health promotion, old population.

$$
\begin{aligned}
& \text { تقييم سلوكيات تعزيز الصحة وعلاقتها مع مخرجات الصحة لاى كبار السن } \\
& \text { العلوم التمريضية السريرية، كلية التمريض، جامبلة اللطيف الموصل، الموصل، العراق }
\end{aligned}
$$

المحتوى: تعزيز الصحة هو السلوك الذي يقوم به الفرد ليمنع المرض ويرفع مستوى الصحة، وهو يقلل الوفيات و العوق ويحسن

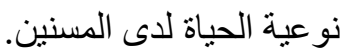

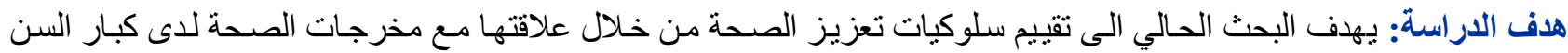

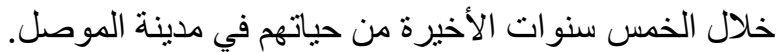

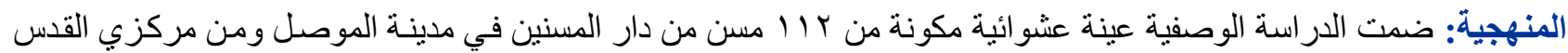

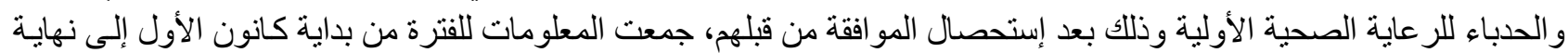

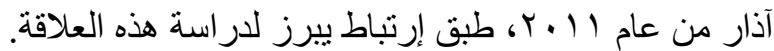

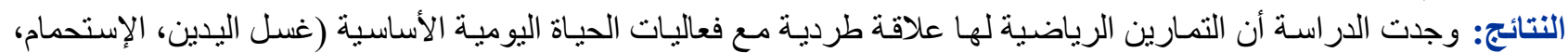

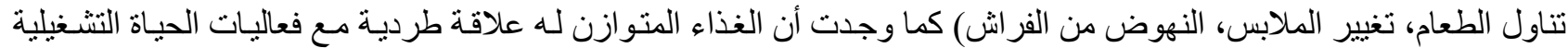

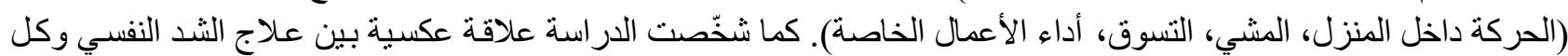
من فعاليات الحياة الأساسية و التشغيلية، كما وجدت بين التقييم الذاتي للصحة وكل التيات من التمارين الرياضية و الغذاء المتوازن. 


$$
\begin{aligned}
& \text { الإستنتاج: تستتنج الدر اسـة أن سلوكيات تعزيز الصـة ضـعيفة الى حد مـا بين المسنين و إنها مقتصرة حول التمـارين الرياضية } \\
& \text { والغذاء المتوازن. } \\
& \text { التوصيات: توصي الدراسة بضرورة النهوض بسلوكيات تعزيز الصحة للمسنين من خلال مر اكز متخصصة لهذا الغرض من أجل } \\
& \text { توفير حياة صحية لهم . } \\
& \text { الكلمات المفتاحية: الغذاء المتوازن، النشاط البدني، تعزيز الصحة، كبار السن. }
\end{aligned}
$$

\section{INTRODUCTION}

ncreasing numbers of senior people is clearly defined in both developed and developing countries. There is a quasi-agreement that old age is considered when person reachs 65 years or older. ${ }^{1}$ In 2005 the number of old age in Iraq was 906000 divided into and three groups; $65-74$ years old were (526000), 75-84 years old were (283000), 85 years and older (97000), all forming $4.5 \%$ of total population. ${ }^{2}$

Although aging is a complex and dynamic process with physiological, psychological and sociological components, ${ }^{1}$ but a successful aging and maintain high level of wellness among old persons can be achieved, this act needs central concerns from gerontologist. ${ }^{3}$ Usually elderly define health in term of ability to function independently and effectively regardless of the presence of disease. ${ }^{3,4}$ Measures to prevent disability and enhance functional status can reduce current health care cost for the elderly by $38 \%$. Another estimate that health promoting measures can prevent or postpone $80 \%$ of all health problems, ${ }^{5}$ physical exercise improves to controls arthritis and limits it's disability effect. ${ }^{3}$

Health promotion refers to those behaviors in which one engages for the aim of preventing disease and enhance wellbeing, it is beneficial in older adult in reducing death and disability and improving quality of life, this is done by slowing down processes of decline and maintaining high level physical functioning. ${ }^{6-8}$

By 2030 the elderly population throughout the world is expected to increase to 973 million, and the number of old adult will be more than triple in developing countries which will account for $71 \%$ of the world elderly population. ${ }^{5}$ As the world population ages, there will be a growing demand for health care services that improve the quality of life as well as longevity. This can be seen in the national health objectives for 2010 addressing the health needs of elderly. A major threat throughout these objectives is to reduce activity limitation that impair the quality of life for older persons. ${ }^{5}$

The objective of the study is to assess health promoting efforts of old population in relation to their physical activity.

\section{METHODOLOGY}

The study used a case series design, after obtaining a formal consent from the participants, data were collected from random sample of 112 old persons. Simple random technique was used. The eligibility criteria required that the participants be at 65 years or older and they live in Mosul city. The sample was collected from the residents of elderly home in Mosul city and from those visiting two main health care centers, AL Hadbba and AL Qudis family medicine centers seeking health care for their acute or chronic illnesses at right and left sides of the city, data was collected through a period of three months from beginning of January to the end of March 2011.

To achieve the study objectives a special tool was used that it is consisted from three parts; the first part reflects the socio demographic characteristics of the study sample includes age, sex, residence, number of family members, previous and present work, and educational level. The second part includes predictors of health promoting activities for the last five years of their lives in which the investigator asked each participant about certain activities like exercise, avoidance of smoking and alcohol, stress management, frequent medical check up and balanced healthy diet. The responses arranged in a rating scale consisted from three options (never, sometimes and always). The third part of the tool is reflecting the health outcomes variables which was concentrating on the physical functioning of the respondents and includes:

1. Number of chronic health problems or diseases.

2. Presence of disability. 
3. Subjectively rated health.

4. Hospitalization.

For health problems, the chronic conditions subscale of Older American Resources Study was used. $^{9}$ Items include: arthritis, osteoporosis, orthopedic problems, heart problem, hypertension, cardiovascular problem, asthma, emphysema or chronic bronchitis, cancer or leukemia, stroke or diabetes, gastrointestinal or liver disorder and urinary tract problems.

Disability or limitation for both basic activities of daily living (ADL) and instrumental activities of daily living, both derived from OARS functional limitation subscale, value of zero for no difficulty and one for difficult basic activities of daily living include washing, bathing, dressing, and putting on shoes, toileting, getting in/out of bed and eating. Instrumental activities of daily living includes getting upstairs, short walk in between rooms, long walk outside home, work duties, home duties, shopping and food preparation.

Subjectively rated health was assessed by self report of health in response to questions considering health of old persons over the past five years as: very poor, poor, fair, good and excellent. For hospitalization, respondents were asked to recall the number of times they were hospitalized for the last five years: as no hospitalization, one or more times of hospitalizations.

Mean of scores and pears correlation was used for statistical analysis of the presented data. ${ }^{10}$ Mean of scores for each item equal to summation of frequencies multiplied by its rating then divided by number of sample, value of 1.5 and more is significant.

\section{RESULTS}

Table 1 shows that $(53.6 \%)$ of the study sample at 65-69 years of age, (58\%) of them females, $(90.2 \%)$ from urban residence, $(55.4 \%)$ of them were married. In all, (32.1\%) were illiterate,35 $(31.3 \%)$ were educated to secondary and higher level, only (39.3\%) gave history of employment.

The Table 2 shows significant result in performing exercise and in taking balanced diet. There was a deficiency in other areas as: avoidance of smoking, stress management and regular medical check up.

Table 3 shows that exercise which is one of health promoting behaviors is significantly predictive for less limitation of Basic activities of daily living in a proportional relation (0.321), balanced diet is also significantly predictive for less limitation of Instrumental activities of daily living in a proportional relation (0.321). Inverse relation was found between stress management and both BADL and IAD (-0.525) and (-0.356), also between exercise and subjectively related health $(-0.356)$, and between balanced diet and subjectively related health $(-0.525)$.

Table 1. Distribution of the study sample according to socio demographic characteristics $(\mathrm{No}=112)$.

\begin{tabular}{lcc}
\hline Age & No. & $\%$ \\
\hline $60-69$ years & 60 & 53.6 \\
$70-79$ years & 38 & 33.9 \\
80 years older & 14 & 12.5 \\
Gender & & \\
Males & 47 & 42 \\
Females & 65 & 58 \\
Residence & & \\
Rural & 11 & 9.8 \\
Urban & 101 & 90.2 \\
Marital status & & \\
Widow & 40 & 35.7 \\
Divorced & 5 & 4.5 \\
Single & 5 & 4.5 \\
Married & 62 & 55.4 \\
Educational level & & \\
Illiterate & 36 & 32.1 \\
Read and write & 13 & 11.6 \\
Primary school & 28 & 25.0 \\
Secondary school & 16 & 14.3 \\
College \& above & 19 & 17.0 \\
Occupation & & \\
Housewife & 24 & 21.4 \\
Unskilled & 24 & 21.4 \\
Skilled & 20 & 39.3 \\
Employed & 44 & \\
\hline
\end{tabular}

Table 2. Mean scores of health promoting activities for the last five years of life among the study sample.

\begin{tabular}{llc}
\hline & Health promoting activities & $\begin{array}{c}\text { Mean of } \\
\text { scores }\end{array}$ \\
\hline 1. & Avoidance of smoking & 1.23 \\
2. & Exercise & $1.63^{*}$ \\
3. & Stress management & 1.17 \\
4. & Regular medical check up & 1.12 \\
5. & Balanced diet & $1.55^{*}$ \\
\hline
\end{tabular}

${ }^{*}$ Mean of scores of $\geq 1.5$ is significant. 
Table 3. Pearson correlation between physical health outcomes and dependent variables of health promoting behaviors among the study sample $(n=112)$.

\begin{tabular}{|c|c|c|c|c|c|}
\hline Health Behaviors & $\begin{array}{c}\text { Basic } \\
\text { ADL }\end{array}$ & $\begin{array}{c}\text { Instrumental } \\
\text { ADL }\end{array}$ & $\begin{array}{c}\text { Numbers } \\
\text { Of health conditions }\end{array}$ & $\begin{array}{c}\text { Subjective } \\
\text { Related health }\end{array}$ & $\begin{array}{l}\text { Hospital } \\
\text { Admission }\end{array}$ \\
\hline $\begin{array}{l}\text { Avoidance of } \\
\text { smoking }\end{array}$ & -0.028 & -0.098 & 1 & -0.047 & -0.077 \\
\hline exercise & $0.321^{*}$ & 1 & -0.098 & $-0.356^{*}$ & -0.016 \\
\hline Stress management & $-0.525^{\star}$ & -0.356 * & 0.047 & 1 & 0.124 \\
\hline $\begin{array}{l}\text { Balanced healthy } \\
\text { diet }\end{array}$ & 1 & $0.321^{*}$ & -0.028 & $-0.525^{\star}$ & -0.054 \\
\hline $\begin{array}{l}\text { Frequent medical } \\
\text { check up }\end{array}$ & -0.054 & -0.016 & -0.077 & 0.124 & 1 \\
\hline
\end{tabular}

\section{DISCUSSION}

This research focuses on health promoting behaviors and their preventive impact on long term quality of life and physical health of old population, We hoped to contribute to more comprehensive understanding of the role of prevention and proactivity in attainment of successful aging. The study concluded that health promoting behaviors among old population were poorly performed when compared with curative one, it is only significant for exercise and for taking healthy balanced diet, this result might be attributed to poor definition of health promotion among them and they might not be familiar to such activities as the youngest group of population in which a new concepts of health promoting life style were adopted. A $17 \%$ of the study sample have higher education, this may explain the defect in conducting this behaviors. Other study found that certain reasons for not engaging in health promoting activities among old population were the advanced age, not being told to do by their health care providers and having no interest in pursuing abnormal findings, so health care provider should consider it as individual approach and help older adults make their own decision about participation in these activities. ${ }^{11}$ The linkage between educational level and health promotion is of Interest, it is founded that education, income are linked to health outcomes, ${ }^{12}$ this may explain the poor engagement of old person taken by this study in a health promoting activities because $(32.1 \%)$ of the sample were illiterate, $(11.6 \%)$ just read and write.

The main result in this study is that exercise is significantly predictive for Little Basic Activities of Daily Living limitation, this result go with result of Gardner et al in which exercise has been shown to result in fewer limitation in activities among old persons like washing and bathing, dressing, putting on shoes, eating getting in /out of bed. ${ }^{13}$ Weight reduction is an important part in the prevention of osteoarthritis, along with moderate exercise. $^{14}$

This study also shows that good balanced diet is predictive for improving Instrumental Activities of Daily Living as getting from room to room, going out of doors, walking up and down stairs, doing own house work, shopping, this is similar to the results of Amarantose et al, who reported a remarkable improvement of quality of life and physical functioning with good balanced diet for elderly. ${ }^{15}$ No positive significant result is found in this study between smoking and the health outcomes, this may be attributed to the fact that $30 \%$ of study sample were smoker males for more than 20 years of their lives.

A considerable limitations were found in this study, a lot of difficulties arises in collecting such a sample of elderly with difficult communication, the residents of Mosul elderly home not exceeding 60, and many of them unfit for interview. In addition to difficulties in finding similar published studies in our locality to be a source for proper comparison of the findings.

\section{CONCLUSION}

The old population included in this study show poor enrollment in health promoting activities and programs, some activities like exercise, healthy diet related to less limitation of both Basic and Instrumental Activities of Daily Living. 


\section{RECOMMENDATION}

Health promotion is a basic building block of health, so the community in need for continuous health promoting programs which should be developed through a special centers and through educational curricula in order to improve healthy behaviors, attention also should be given to older adult who should live a health promoting life style.

\section{REFERENCES}

1. Alford D, Futrell M. Wellness and Health Promotion of the Elderly, Journal of Gerontology Nursing. 2007; 40(5): pp 221-226.

2. Ministry of planning and development, center statistical and information technology, directorate for cemm and man power. 2005; p18.

3. Susan A .Significance of health promotion to older adults, Journal of Holistic Nursing, American Holistic Nurses Association. 1998; 16(3): pp356-357.

4. Kahana E, Kahana B. Contextualizing successful aging; Invitation to the life course; toward a new understanding of late life. Amityville (NY): Baywood Publishing, 2003; pp225-55.

5. Clark M. Community health nursing, care of old population, promoting healthy life style, $5^{\text {th }}$ edition, USA, Saunders company. 2008; pp 873-874.

6. Mary A, Melanie McEwen. Community/Public Health Nursing. Health Promotion and Risk Reduction. $6^{\text {th }}$ edition, Saunders, 2011; pp361-362.
7. Varrama $M$, Pieper $R$, Sixsmith $A$. Care related quality of life in old age. $4^{\text {th }}$ edition, springer, 2008;pp; 32-36.

8. Chai W, Nigg C, Pagano L, Dishman R. Association of quality of life with physical activity, International Journal of Behavioral Nutrition and Physical Activity. 2010; 83(7): 83-84.

9. George L and Fillenbaum G. OARS Methodology. A decade of experience. J Am Geriatric Society. 1995; 33: 607-15.

10. Moore D, William I, Michael A. Basic practice of statistics, $6^{\text {th }}$ edition, USA, W.H. Freeman \& company. 2013; pp 8-11.

11. Gatterman MI. Chiropractic and Health Promotion and Wellness. Sudbury, Mass.: Jones \& Bartlett, 2007; pp 88-89.

12. Akinpelu A, Alonge $T$, Adekanla $B$, Odole $A$. Prevalence and pattern of symptomatic osteoarthritis in old age in Nigeria. Journal of Allied Health Sciences and Practice. 2009; 7(3): pp 2-3.

13. Gardner M, Robertson M, Campbell A. Exercise in preventing falls and fall related injuries in older people: a Review of randomized control trials. British Journal of Sport Medicine.2005; 34(1): pp 7-17.

14. Jamison JR. Maintaining Health in Primary Care. Guidelines Wellness in the $21^{\text {st }}$ Century. St. Louis: Churchill Livingstone, 2001; pp 10.

15. Amarantose E, Martinez A, Dwyer J. Nutrition and quality of life in older adults, Journal of Gerontology, 2001; 56(2): s54-56. J Nippon Med Sch 2008; 75: 269273. 